\title{
OBITUARY
}

\section{EDWARD ROBERT STRAKER}

Mr STRaker died at St Albans on 24 January r94I, at the age of 81 . The last ten years of his life were overclouded by a serious illness which confined him to his room. He was thus unknown, except in name, to junior members of the Institute, but was held in affectionate memory by those who were fortunate enough to have enjoyed his intimate friendship.

Straker's insurance career extended over thirty-nine years, all of which, until his retirement in 1919 , was spent in the service of the "Phoenix" and its associated companies. He joined the staff of the "Lion" in I880. Three years later, when this company was absorbed by the "British Empire Mutual", he became an actuarial assistant in the latter office. He was appointed Assistant Actuary in 1897, Actuary of the "Pelican and British Empire" in 1903, and Actuary of the "Phoenix" in Igo8.

His Fellowship degree of the Institute dates from I892. He served on the Council in 1906-10 and again in 1917-19. He also, for a time, served as examiner.

He was always a student, and with him no time or trouble was too great to ensure meticulous accuracy. Moreover, he was always ready to give his juniors the benefit of his knowledge and experience by explaining any points of principle which arose in connexion with their work. At least four men who served their early apprenticeship under Straker have since attained distinction as chief officers of important Companies. They would be the first to admit that they owe some debt to him for their eariy training.

Never seeking the "limelight" himself, he was always a more zealous advocate of the claims of others than of his own. High ideals and unselfish interest in the welfare of his colleagues were the motives of his lovable character.

A. T. W. 